\title{
Demographic Situation in the Buryatia and Kalmykia
}

\author{
Ekaterina Kovanova ${ }^{1},{ }^{*}$ Sayan Alekseyev ${ }^{2}$, Nogan Badmaeva ${ }^{3}$ \\ ${ }^{1}$ KSU named after B.B. Gorodovikov, Elista, Russia \\ ${ }^{2}$ ESSU of Technology and Management, Ulan-Ude, Russia \\ ${ }^{3} \mathrm{KSC}$ of the RAS, Elista, Russia \\ *Email: ekovanova@yandex.ru
}

\begin{abstract}
The subject of the study is demographic processes in the Mongolian-speaking regions of Russia. Modern demographic processes in the country's regions strongly depend on the socio-economic development of territories, which in turn have significant territorial differentiation. The analysis of demographic trends in Kalmykia and Buryatia will allow us to determine whether there are features of population reproduction in these regions have similar and distinctive features. The article uses data from the All-Russian Population Census of 2002 and 2010. A comparative analysis of the regions' demographic indicators under consideration with Mongolia's indicators is carried out.
\end{abstract}

Keywords: Demographic, Mongolian-speaking regions, Population reproduction, Migration

\section{INTRODUCTION}

Buryatia and Kalmykia are two republics in Russia, which include the Mongolian-speaking people. The areas occupy 71 st and 80th places, according to the rating of the economic situation of the regions Russia in 2020 and ranking 81st and 76th among the country in terms of quality of life, respectively [1-3].

Many researchers assess depopulation processes in the country as a threat to the state's national security. One of the current problems remains the low population density in Russia - approximately 8.3 people per $1 \mathrm{~km}^{2}$ (5 times less than the global average). This indicator is significantly lower than the national average in the regions under consideration. Low population density is associated with a considerable area of the country combined with harsh natural conditions in most Russia.

The social conditions and factors in these districts are mainly comparable to those observed in Mongolia [4, p. 119].

\section{DEMOGRAPHIC PROCESSES IN KALMYKIA AND BURYATIA}

The population of Buryatia higher than the population of Kalmykia (Table 1). The population of Kalmykia has decreased by 19,497 people in 10 years; the population of Buryatia has grown by 13,410 people over the same period.

According to Table 1, a significant proportion of the rural population in the republics. The share of the rural population in Kalmykia tends to decrease while the urban population is increasing. In Buryatia, the share of the rural population is significantly lower than in Kalmykia. At the same time, the gender disparity is most pronounced in Buryatia.

The population of Buryatia is 3.7 times higher than the population of Kalmykia (Table 1). The population of Kalmykia has decreased by 19,497 people in 10 years; the population of Buryatia has grown by 13,410 people over the same period.

According to Table 1, a significant proportion of the rural population in the republics. The share of the rural population in Kalmykia tends to decrease while the urban population is increasing. In Buryatia, the share of the rural population is significantly lower than in Kalmykia. At the same time, the gender disparity is most pronounced in Buryatia. According to Rosstat, this proportion is typical for almost all regions of Russia.

According to the 2010 census, the Russian population prevailed in Buryatia [5]. In Kalmykia, according to the results of the 2010 census, the Russian population 
Table 1. Characteristics of the demographic situation in the Republics of Kalmykia and Buryatia

\begin{tabular}{|l|c|c|c|c|}
\hline \multirow{2}{*}{} & $\begin{array}{c}\text { The total population as } \\
\text { of 01.01.2021, thousand } \\
\text { people }\end{array}$ & \multicolumn{2}{|c|}{$\begin{array}{c}\text { The ratio of urban and rural } \\
\text { population, \% }\end{array}$} & $\begin{array}{c}\text { The number of women } \\
\text { per 1,000 men, people. }\end{array}$ \\
\cline { 3 - 5 } & & $\begin{array}{c}\text { urban } \\
\text { population }\end{array}$ & rural population & \\
\hline Republic of Kalmykia & 269.98 & 46.2 & 53.8 & 1,082 \\
\hline Republic of Buryatia & 985.43 & 59.1 & 40.9 & 1,100 \\
\hline
\end{tabular}

Source: Compiled by the authors according to [5-8].

accounted for $29.6 \%$ of the republic's total population. The Kalmyk population is $56.2 \%$ [6, pp. 7-8] (Figure 1).

The working-age population in Kalmykia and Buryatia is almost the same and amounts to $55-56 \%$. At the same time, the proportion of the population older than working age in Kalmykia is higher [9].

Buryatia is among the top ten regions with a high birth rate, but it has tended to decrease in recent years. In Kalmykia, the birth rate decreased considerably in 2017, although until 2016, it was higher than all-Russian indicators. In 2019 Buryatia ranked 8th in the country in terms of fertility. Kalmykia - 31st place [10].

From 2005 to 2019, the mortality rate in Kalmykia was significantly lower than the all-Russian indicator and lower than in Buryatia. It should be noted that the mortality rate in Russia as a whole and in the republics under consideration has significantly decreased. According to this indicator, in 2019, Kalmykia took 12th place among Russian regions, Buryatia - 20th. The highest mortality rates in Russia, including Kalmykia and Buryatia, occurred in 2005 [10].

\section{CHARACTERISTICS OF DEMOGRAPHIC PROCESSES IN MONGOLIA}

In 2015, the country's population reached three million people. This year, 3.1 children accounted for one woman of fertile age $[11,12]$. In 2020 , the population was $3,278,292$ people [10]. The birth rate per 1,000 people was 23.4 in 2019 . The mortality rate was 6.3 [13, 14].

The researchers note that the ideal number of children in Mongolia has consistently been about three to four children over the past 20 years. There are no preferences in favour of boys compared to other Asian countries [15].

Mongolian society has a tradition of high spatial mobility, which differs from social mobility since they physically move from one place to another, but still, depend on traditional cattle breeding within open or semi-open pasture resources.

Climate change is changing Mongolia, especially in rural areas. [16]. The average annual surface temperature has increased by 2.24 degrees Celsius over the past 80

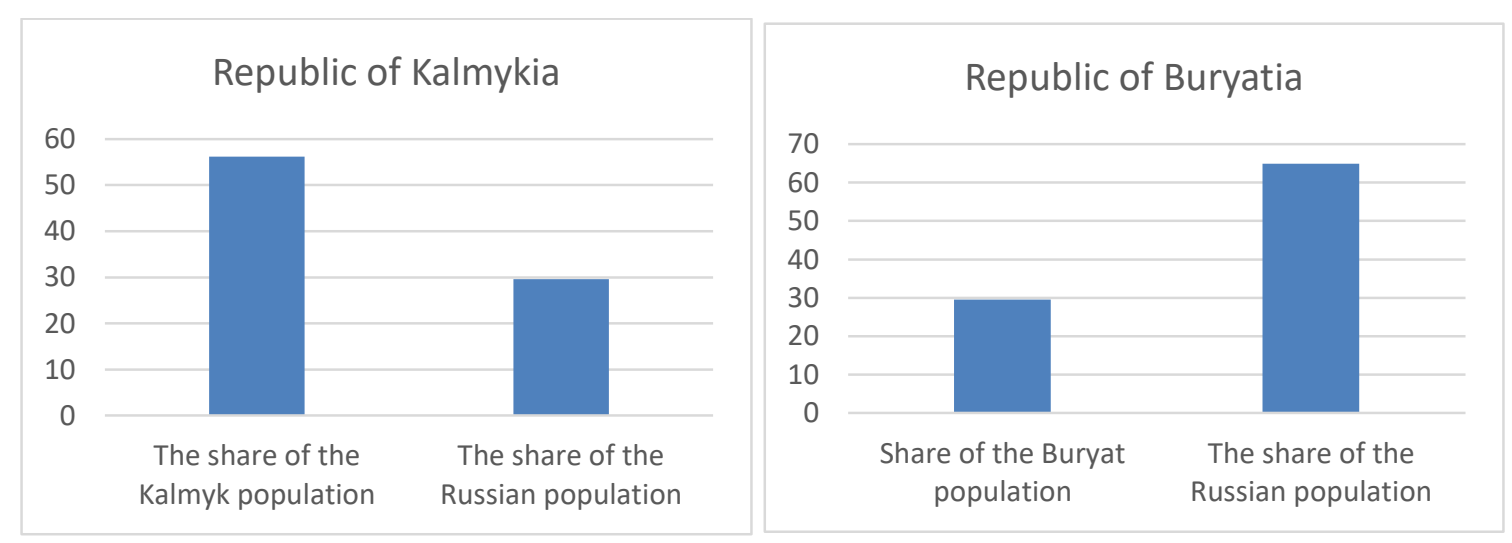

Figure 1 The population of the regions by nationality according to the All-Russian Population Census 2010. 
Table 2. Birth and mortality rates in 2019

\begin{tabular}{|l|c|c|}
\hline \multicolumn{1}{|c|}{ Region/Country } & Birth rate & Mortality rate \\
\hline Republic of Kalmykia & 10.3 & 9.4 \\
\hline Republic of Buryatia & 12.7 & 12.3 \\
\hline Russian Federation & 10.1 & 6.3 \\
\hline Mongolia & 23.4 & 11 \\
\hline
\end{tabular}

years, about three times more than the world average [1719]. In addition to temperature changes, there has been a downward trend in precipitation since 1950. Unstable precipitation distribution and droughts have been more frequent in recent decades [20].

\section{COMPARATIVE ANALYSIS OF DEMOGRAPHIC INDICATORS RUSSIA (BURYATIA, KALMYKIA) AND MONGOLIA}

In Buryatia, the indicator of life expectancy is significantly lower than both the all-Russian indicator and the indicator in Kalmykia (Table 2). According to this indicator, in 2019, Buryatia ranked 72nd among the subjects of the Russian Federation. In Kalmykia, the indicator of life expectancy among men from 2005 to 2019 increased from 61.17 to 69.32 years. According to this indicator, Kalmykia ranked 13th among the subjects of the Russian Federation. In Buryatia, this indicator is significantly lower than the all-Russian indicator and amounted to 65.36 years in 2019. According to this indicator, Buryatia took 74th place. According to the indicator of total life expectancy among women in 2019, Kalmykia took 6th place among the country's regions; life expectancy was 80.27 years. In Buryatia among men, this indicator is significantly lower than the all-Russian one and amounted to 76.12 years (73rd place among the subjects of the Russian Federation) [10].
According to table 3 , the share of the population under 14 in Kalmykia and Buryatia exceeds the allRussian indicator. Still, these indicators lag far behind the indicator in Mongolia. The largest share of the population aged 15 to 64 years is observed in the Republic of Kalmykia, while the share of the population of this age group in the regions under consideration does not differ much. The share of the elderly population in Russia and the regions under consideration is more than three times higher than the share of the older population in Mongolia. At the same time, this indicator in Kalmykia and Buryatia is lower than the all-Russian indicator. As we can see, Kalmykia and Buryatia are characterised by an allRussian trend of population ageing.

The number of marriages in the regions under consideration has decreased for a long time. The marriage model is changing, and the proportion of persons in unregistered marriages is growing. The age of marriage is increasing, the birth of children is postponed to a later date. The ratio of marriages and divorces is most clearly represented among the population of the Republic of Kalmykia. Thus, there were 457 divorces per 1,000 marriages in 2005 in the Republic of Kalmykia, and in 2019 - 753 divorces per 1,000 registered marriages [10].

The analysis of demographic processes in Kalmykia and Buryatia has shown that each of these regions has its own set of factors: historical (deportation of Kalmyks) or regional (agrarian for Kalmykia and industrial-agrarian for Buryatia specifics of the economy; natural and

Table 3. Population by age group in 2020

\begin{tabular}{|l|c|c|c|}
\hline \multicolumn{1}{|c|}{ Region/Country } & $0-14$ years old & $15-64$ years old & 65 years and older \\
\hline Republic of Kalmykia & 20.2 & 67.04 & 12.7 \\
\hline Republic of Buryatia & 23.2 & 65 & 11.8 \\
\hline Russian Federation & 17.7 & 66.5 & 15.8 \\
\hline Mongolia & 31.1 & 64.6 & 4.3 \\
\hline
\end{tabular}

Source: Compiled by the authors according to [21, 22, 23]. 
environmental (desertification in Kalmykia, soil degradation), managerial and political, to some extent influencing the demographic problems of the republics. Although regional indicators differ in certain indicators, it is essential to note that in the process of population reproduction in the republics, there are problems that will tend to worsen in the future. Also, in the republics with agrarian specifics, the share of the rural population is decreasing, which indicates the decadent state of the agro-industrial complex in the regions. Also, as in Russia as a whole, the share of the elderly population in the republics is increasing, which leads to the ageing of the population as a whole, which also affects the process of population reproduction.

\section{CONCLUSIONS}

Negative trends characterise the demographic situation in the republics under consideration. Since the collapse of the USSR, in the regions under consideration, as in many others, there has been a decline in the economy: high unemployment, low incomes, etc., which has strengthened not only socio-economic but also demographic differentiation of the country's regions. Among the subjects of the Russian Federation, the highest birth rates are observed in national republics (Dagestan, Chechnya, Ingushetia, Tuva, etc.), in which traditional and religious values influence the demographic development of these regions.

\section{FINANCING}

The article was prepared within the framework of the project RFBR grant 19-010-01082.

\section{REFERENCES}

[1] Rating of the socio-economic situation of the regions - 2020 [Rejting social'no-ekonomicheskogo polozheniya regionov - 2020] [Electronic resource]. URL:

https://riarating.ru/infografika/20200602/63017051 3.html (accessed 02.10.2021).

[2] The rating of the regions of the Russian Federation by the unemployment rate -2020 [Rejting regionov RF po urovnyu bezraboticy - 2020] [Electronic resource].

URL: https://riarating.ru/infografika/20200317/63015772 3.html (accessed 02.10.2021).

[3] Quality of life in Russian regions - Rating 2020 [Kachestvo zhizni v rossijskih regionah - Rejting 2020] [Electronic resource]. URL: https://riarating.ru/infografika/20210216/63019463 7.html (accessed 05.10.2021)

[4] Z.A. Danilova, Social risks in Baikal Asia (based on the materials of Buryatia and Mongolia) [Social'nye riski v Bajkal'skoj Azii (na materialah Buryatii i Mongolii)]// Problems of forecasting [Problemy prognozirovaniya] 1 (2015) 119-128.

[5] Estimation of the permanent population as of January 1, 2021 [Ocenka chislennosti postoyannogo naseleniya na 1 yanvarya 2021 goda] [Electronic resource]. URL: https://astrastat.gks.ru/folder/35673 (accessed 02.10.2021).

[6] The population of the Republic of Buryatia on January 1 [Naselenie Respubliki Buryatiya na 1 yanvarya] [Electronic resource]. URL: https://burstat.gks.ru/demo (accessed 02.10.2021).

[7] The national composition of the population of the Republic of Buryatia according to the ARC-2010 results [Nacional'nyj sostav naseleniya Respubliki Buryatiya po rezul'tatam VPN $2010 \mathrm{~g}$.] [Electronic resource]. URL: https://burstat.gks.ru/vpn2010 (accessed 04.10.2021).

[8] National composition and language proficiency, citizenship: results of the All-Russian Population Census 2010, Elista: Territorial body of the Federal State Statistics Service for the Republic of Kalmykia [Nacional'nyj sostav i vladenie yazykami, grazhdanstvo: itogi Vserossijskoj perepisi naseleniya 2010 goda. Elista:Territorial'nyj organ federal'noj sluzhby gosudarstvennoj statistiki po Respublike Kalmykiya], 2013, 841 p.

[9] The proportion of the urban and rural population in the total population. Regions of Russia. Socioeconomic indicators - 2020 [Udel'nyj ves gorodskogo i sel'skogo naseleniya v obshchej chislennosti naseleniya. Regiony Rossii. Social'noekonomicheskie pokazateli - 2020 g.] [Electronic resource].

URL: https://gks.ru/bgd/regl/b20_14p/Main.htm (accessed 17.10.2021).

[10] Statistical collection "Regions of Russia. Socioeconomic indicators - 2020" [Statisticheskij sbornik «Regiony Rossii, Social'no-ekonomicheskie pokazateli - 2020 g.»] [Electronic resource]. URL: https://gks.ru/bgd/regl/b20_14p/Main.htm (accessed 15.10.2021).

[11]E. Byambaa Fertility preferences in Mongolia // Family Demography in Asia, Edward Elgar Publishing, 2018, pp. 197-208. DOI: https://doi.org/10.4337/9781785363559.00018

[12] M. Judger, B. Baffour, Z. Zhao, Recent fertility changes in Mongolia: what can we learn from examining tempo-adjusted fertility? // Asian Population Studies, 2021, pp. 1-19. 
[13] Mongolia - Crude birth rate (2019) [Electronic resource]. URL: https://knoema.com/atlas/Mongolia/Birth-rate (accessed 17.10.2021)

[14] Mongolia — Crude death rate (2019) [Electronic resource].

URL: https://knoema.com/atlas/Mongolia/Death-rate (accessed 17.10.2021).

[15] Y. Xu, Y. Zhang, J. Chen, Migration under economic transition and changing climate in Mongolia // Journal of Arid Environments 185 (2021) 104333.

[16] M.P. Rao et al., Dzuds, droughts, and livestock mortality in Mongolia // Environmental Research Letters 10(7) (2015) 074012.

[17] S. Schoening, Lessons from internal climate migration in Mongolia // Forced Migration Review 64 (2020) 22-24.

[18]H. Park et al., Urbanisation on the Mongolian Plateau after economic reform: Changes and causes // Applied Geography 86 (2017) 118-127.

[19] Estimation of the permanent population as of January 1, 2021 [Ocenka chislennosti postoyannogo naseleniya na 1 yanvarya 2021 goda] [Electronic resource]. URL: https://astrastat.gks.ru/folder/35673 (accessed 02.10.2021).

[20] Distribution of the Russian population by age groups [Raspredelenie naseleniya Rossii po vozrastnym gruppam] [Electronic resource]. URL: https://rosstat.gov.ru/folder/12781 (accessed 05.11.2021). 